\title{
With or Without Marx? With or Without Capitalism? A Re- joinder to Adam Arvidsson and Eleanor Colleoni.
}

\author{
Christian Fuchs
}

Uppsala University, Department of Informatics and Media, Sweden. christian.fuchs@im.uu.se, http://fuchs.uti.at

\author{
Abstract: This paper is a rejoinder to an article by Adam Arvidsson and Eleanor Colleoni: \\ Arvidsson, Adam and Eleanor Colleoni. 2012. Value in informational capitalism and on the Internet. The Information Society \\ 28 (3): 135-150. \\ Arvidsson and Colleoni's paper is a criticism of and reaction to one of my own articles: \\ Fuchs, Christian. 2010. Labor in informational capitalism and on the Internet. The Information Society 26 (3): 179-196. \\ My comments focus on 6 aspects of discussion: \\ 1) Misunderstandings of Marx \\ 2) Autonomous Marxism \\ 3) Corporate social media and the law of value \\ 4) Capital accumulation on social media \\ 5) Finance capital and social media \\ 6) Politics, alternatives, and social transformation \\ The discourse constituted by the two articles and this rejoinder are situated in the context of the digital labour debate that \\ can be considered to constitute an important part of the contemporary discourse of the political economy of the media and \\ the Internet. It is recommended that you first read both previous articles before reading this rejoinder.
}

Keywords: digital labour, law of value, Marxist labour theory of value, capitalism, Internet, social media

This contribution is a rejoinder to Adam Arvidsson and Eleanor Colleoni's (2012) article "Value in informational capitalism and on the Internet" that was published in the journal The Information Society and that is a reaction to my paper "Labor in informational capitalism and on the Internet" (Fuchs 2010) that was published in the same journal. The main task of Arvidsson and Colleoni's (2012) article is to argue that the Marxist labour theory of value does not apply to the Internet and informational capitalism and to argue that a new law of value can be constituted by principles of ethical evaluation and affectual relations (affectual law of value).

My comments focus on 6 aspects of discussion:

1) Misunderstandings of Marx

2) Autonomous Marxism

3) Corporate social media and the law of value

4) Capital accumulation on social media

5) Finance capital and social media

6) Politics, alternatives, and social transformation

A lively debate on the topic of digital labour has emerged in recent years (see also the following two collected volumes: Burston, Dyer-Witheford and Hearn 2010, Scholz 2012) that features both Marxist and non-Marxist as well as critical and administrative positions.

\section{Misunderstanding Marx}

The section "Value, Labor, Exploitation: An Overview" in Arvidsson and Colleoni's (2012) paper promises an overview of the Marxist labour theory of value, but in fact does not give a definition of value and does not discuss the difference between values and prices. 
There is a difference between value and price that Marx stressed: The measure of the substance of value of a commodity is the amount of hours needed for its production: "How then is the magnitude of this value [of a commodity] to be measured? By means of the quantity of the 'valueforming substance', the labour, contained in the article. This quantity is measured by its duration, and the labour-time is itself measured on the particular scale of hours, days etc." (Marx 1867, 129). "Every commodity (product or instrument of production) is = the objectification of a given amount of labour time (Marx 1857/58, 140)". Marx formulated the law of value as saying that "the greater the labour-time necessary to produce an article, [...] the greater its value. The value of a commodity, therefore, varies directly as the quantity, an inversely as the productivity, of the labour which finds its realization within the commodity. (Now we know the substance of value. It is labour. We know the measure of its magnitude. It is labour-time" (Marx 1867, 131).

Price is not the same as value: "The expression of the' value of a commodity in gold $x$ commodity $\mathrm{A}=\mathrm{y}$ money commodity - is its money-form or price" (Marx 1867, 189). "Price is the money-name of the labour objectified in a commodity" (Marx 1867, 195f). This means that values are determined at the level of working hours and prices at the level of money. Both are quantitative measures, but use different different units of measurement. Value is a measure of the production process, price a measure of the circulation process (selling) of commodities. Labour is extended in time (and space) in the production process, in which commodities are created, and is transformed into profit (measured as a price in money) in the sphere of circulation, i.e. commodity markets, on which commodities are sold for certain prices. This means that exploitation of labour takes place before the selling of commodities. Even if a commodity is not sold, once it is produced, labour has been exploited.

When introducing the concept of brand value in an article, Adam Arvidsson $(2005,238)$ gives figures of brand values in US\$, which shows that he thinks of value in terms of money (that signifies only the price of a commodity) and not in working hours (that signify the value of a commodity). The definition of brand value as "the present value of predictable future earnings generated by the brand" (Arvidsson 2005, 238) is not only circular and therefore absurd (definition of value by value), but also makes clear that Arvidsson defines value at the price level ("earnings"). Arvidsson and Colleoni (2012) mix up the concepts of labour value and commodity price, e.g. when speaking of a surplus value of $\$ 0.7$ (p. 138). They ignore Marx's insights that there is a difference between value and price of a commodity. Marx $(1857 / 58,137)$ distinguishes therefore between the "real value" and the "nominal value" (price) of a commodity and says that the "price of a commodity constantly stands above or below the value of the commodity, and the value of the commodity itself exists only in this up-and-down movement of commodity prices" (Marx 1857/58, 138). In Hegelian terminology, Marx $(1857 / 58,137)$ suggests that the price is a constant negation of the value of a commodity that results in a "constant negation of the negation" and thereby hints at the fact that this contradiction can be a source of crisis.

\section{Autonomist Marxism}

Arvidsson and Colleoni $(2012,138)$ argue that Michael Hardt and Antonio Negri's concept of the multitude "should be understood as a post-Marxist alternative to 'class'“. But in fact, Hardt and Negri stress multiple times that "multitude is a class concept" (Hardt and Negri 2004, 103). Hardt and Negri consider as orthodox class concepts those, in which "the working class refers to all waged laborers and thus excludes the various unwaged classes" (Hardt and Negri 2012, 106). I precisely follow Hardt and Negri in this respect in my own approach: today, also unpaid workers are productive, they create the commons that are exploited by capital, and are therefore part of the proletariat. This includes the users of Facebook just like the unemployed, houseworkers, and the creators of everyday activities that produce creations of existence of humanity that are also foundations of the existence of capital. An "orthodox Marxist definition of class" (Arvidsson and Colleoni 2012, 138) in contrast holds that only wageworkers are productive workers. Arvidsson takes such an orthodox position when he says that "the labor theory of value only holds if labor has a price " (Arvidsson 2011, 265). 
I do however not claim and in fact have never claimed that my approach is Autonomist Marxist in character. Autonomist Marxism has advanced some interesting concepts - especially the ones of the social worker and the social factory -, but just like with any approach, one should also be critical of it (for a book-length criticism and discussion of Negri's approach see Fuchs and Zimmermann 2009).

Arvidsson's alternative to the Marxist labour theory of value is an idealistic and subjectivist concept of value - ethical value understood as "the ability to create the kinds of affectively significant relations" (Arvidsson 2005, 270) - that ignores the reality of material inequality, precarious labour, and gaps between the rich and the poor. It assumes that everything in the contemporary economy has become affective. Arvidsson follows Negri in the claim that the law of value does not apply to "immaterial/intangible wealth" because this form of wealth would be produced in co-operation and its value would be determined by affects and intersubjective judgments so that an "affect-based law of value" (Arvidsson and Colleoni 2012, 142) would have emerged. Virno $(2003,100)$ says that the law of value is "shattered and refuted by capitalist development itself". Hardt and Negri $(2004,145)$ argue that the "temporal unity of labor as the basic measure of value today makes no sense". Vercellone $(2010,90)$ writes that "cognitive capitalism" has resulted in the "crisis of the law of value" and "a crisis of measurement that destabilizes the very sense of the fundamental categories of the political economy; labor, capital and obviously, value" (90).

The Autonomist-Marxist assumption that the law of value no longer applies today is not feasible because this law is a foundation for the existence of capitalism and because the assumption is based on a false interpretation of a passage from Marx's Grundrisse (that Arvidsson and Colleoni cite on pages 139f; see also Arvidsson 2006, 136, for the same kind of argument), in which Marx says that "labour time ceases and must cease to be" the measure of wealth (Marx 1857/58, 705). The misinterpretation is precisely that Marx here describes a transformation of "the relations of value appropriation (or exploitation) that prevail within capitalism" (Arvidsson and Colleoni 2012, 139). Instead Marx in the same passage makes clear that he talks about a situation, in which the "mass of workers" has appropriated "their own surplus labour" (Marx 1857/58, 708). "Once they have done so - and disposable time thereby ceases to have an antithetical existence - then, on one side, necessary labour time will be measured by the needs of the social individual, and, on the other, the development of the power of social production will grow so rapidly that, even though production is now calculated for the wealth of all, disposable time will grow for all" (Marx 1857/58, 708). Marx talks about a society, in which "production based on exchange value breaks down" (Marx 1857/58, 705) - a communist society. Arvidsson and Colleoni do not cite or mention this context of the discussed passage. Marx describes how the rise of technology and knowledge in capitalism advances the antagonism between necessary and surplus labour time and the productive forces and relations of production and that this antagonism creates the foundations of a communist society, in which free time is the measure of wealth and available to a maximum degree for all.

Whereas Arvidsson and Colleoni share with some Autonomous Marxism this misinterpretation of Marx, they, as I will argue, do not share much else with any form of Marxism, be it Autonomous or non-Autonomous.

\section{Corporate Social Media and the Law of Value}

Arvidsson $(2011,273)$ argues that I have come to the "absurd suggestion that Facebook users are subject to 'infinite levels of exploitation' since the exchange value of their labor is zero". Arvidsson and Colleoni write: "If Facebook made a profit of \$ 355 million in 2010 [...], this would mean that each Facebook user was a 'victim of exploitation of surplus value' to the extent of $\$ 0.7$ a year, [...] hardly [...] 'a rate of exploitation that converges towards infinity' as Fuchs claims" (Arvidsson and Colleoni 2012, 138).

Arvidsson and his colleague mix up the levels of value and price as well as the sphere of commodity production and the sphere of commodity circulation. If 500 million people use a corporate platform that is funded by targeted advertising for an average of 90 hours a year (which is on aver- 
age 15 minutes a day), then the value created is 45 billion hours of digital labour. All of this online time is monitored and creates a traffic commodity that is offered for sale to advertisers, none of the time is paid. 45 billion hours of work are therefore exploited. Exploitation is constituted by the unpaid work time that is objectified in a commodity and appropriated by capital. To which extent the data commodity can be sold is a question of the transformation of value into profit. If not enough data commodities can be sold, then the profit will be low. Workers are however also exploited if the commodities they create are not sold because value and surplus value of a commodity are created before it is sold. Arvidsson's criticism implies that exploitation is based in the sphere of commodity circulation and not in the sphere of commodity production. This assumption is absurd because it implies that workers, who create a commodity that is not sold (e.g. because there is a lack of demand), are not exploited.

Users spent 10.5 billion minutes on Facebook per day in January 2011 (Facebook, SEC Filings, Amendment No. 3 to Form S-1 Registration Statement). We can therefore make the following estimates about the value generated on Facebook.

Value generated on Facebook in 2011: 10.5 billion * $365=3832.5$ billion minutes $=63.875$ billion working hours per year.

Average working hours per year of a full-time worker: 1800

Value generated on Facebook in 2011: 35486111 full-time equivalents of work

The rate of exploitation is calculated as the ratio e = surplus labour time / necessary labour time = unpaid labour time / paid labour time. In the case of Facebook, all 64.99 billion working hours were unpaid, so the surplus labour time amounts to the full amount of labour time. Given that Facebook exploits more than 35 billion full-time equivalents of free labour or more than 60 billion hours of unpaid work time, it becomes clear that Facebook's business model is based on the outsourcing/crowdsourcing of paid work time to unpaid work time. Given that Facebook's profits were 1 billion US\$ in 2011 (Facebook, SEC Filings, Amendment No. 3 to Form S-1 Registration Statement), it becomes clear that free user labour is at the heart of Facebook's business model. That the rate of exploitation is infinite means that no wages are paid, that all user labour is unremunerated and creates value. Free user labour is what Marx (1867) termed abstract labour, labour that creates value. At the level of values, we can say that the collective Facebook worker works almost 64 billion hours per year. The surplus hours and surplus work amount to 64 billion hours per year. Personal and social data is the product that is created in this work time. The more hours users work on Facebook, the more data they generate. The more hours users spend on Facebook, the more ads are generated and presented to them. So productive time is also advertising time (although not all advertising time, but only a portion of it, is turned into money profit). From Facebook's balance sheet that was published at its stock market registration, we know that Facebook's profit rate $2011=$ total profit/total costs and expenses $=1$ billion $/ 1.955$ billion $=51.2 \%$ (data source: Facebook Inc., SEC Filings Facebook, Form S-1 Registration Statement). This is a very high profit rate, especially in times of crisis. It can mainly be achieved by the circumstance that Facebook has a low number of employees, roughly 3500 in May $2012^{1}$, but needs the entire work time of its users for generating its commodity - data commodities. Infinite exploitation of the users (= no wage) allowed Facebook a profit rate of $>50 \%$ in 2011. The secret of Facebook's profits is that it mobilizes billion hours of users' work time (at the level of values) that is unpaid (at the level of prices).

The argument that only little profit is generated by a single user is also not convincing due to the fact that unpaid labour extends to different realms, such as Google, Twitter, YouTube, Baidu, Linkedln, knowledge creation and reproduction, "reproductive labour" such as housework, care work, educational work, affective work, sexual work, etc so that the human being in contemporary capitalism spends a lot of working hours every day in creating value for capital by abstract labour that is unpaid. We can therefore say that life has become a factory, factory life. The factory is not limited to the space of wage labour, but extends into everyday life. The secret of corporate social

\footnotetext{
${ }^{1}$ Data source: http://newsroom.fb.com/content/default.aspx?NewsAreald=22
} 
media's capital accumulation strategy is that it mobilizes a huge number of unpaid workers who engage in a tremendous amount of fully unpaid working hours that generate data commodities that are sold as targeted advertisements. There is a need to mobilize value production and to make it free labour at the same time in order for this capital accumulation to function.

Marx described a contradiction between value and labour time: the development of technological productivity reduces the labour time needed for producing a commodity due to technological productivity, but at the same time labour time is the only measure and source of wealth in capitalism: "Capital itself is the moving contradiction, [in] that it presses to reduce labour time to a minimum, while it posits labour time, on the other side, as sole measure and source of wealth. Hence it diminishes labour time in the necessary form so as to increase it in the superfluous form; hence posits the superfluous in growing measure as a condition - question of life or death - for the necessary" (Marx 1857/58, 706). The result of this contradiction is, as contemporary capitalism shows, unemployment and precarious labour. In contemporary capitalism, this contradiction takes on a second meaning and reality that is at the heart of corporate social media's capital accumulation model: Corporate social media capital tries to push down the costs of necessary labour (wages) to a minimum, but at the same time increases superfluous labour that is unpaid productive labour that creates surplus value. The contradiction between necessary and superfluous labour takes on its specific form on corporate social media: paid labour is reduced, unpaid labour is increased, value generation is outsourced from paid to unpaid labour. The contradiction between superfluous and necessary labour is sublated so that a new quality emerges: value-creation is transferred to unpaid labour. At the same time, the contradiction is set at a new level and intensified because the propertylessness, poverty, and precariousness of labour on the one hand and the wealth of capital on the other hand are intensified.

Questioning the labour theory of value in capitalism also means questioning that labour is at the heart of value production and to question that we live in a capitalist society because the basic foundation of capitalist society is that capital is continuously created by labour. The suggestion that the "labor theory of value in fact does not apply" to social media (Arvidsson and Colleoni 2012, 136) therefore means that we do not live in a capitalist society, an absurd assumption. Labour time is the substance of value, which means that capital can only exist based on unpaid labour. According to Marx's labour theory of value, labour in capitalism has a double character as abstract and concrete labour: As concrete labour, it "produces use values" that satisfy human needs (Marx 1867, 137). In this respect, it is the "father of material wealth" (134) and "a condition of human existence". But it is in its historical form also abstract labour, an activity that creates the "value of commodities" (137). Facebook users create use values, such as content, communication, networks, but these use values take on the form of commodities that are sold to advertising clients so that the concrete Facebook labour that satisfies human and social needs is at the same time an abstract, value-generating activity.

Arvidsson argues that labour can only be exploited if labour power has a price, i.e. is sold as a commodity and thereby becomes wage labour: "As a consequence, the labor theory of value only holds if labor has a price, if it has been transformed into a commodity that can in some way be bought and sold on a market. It is clear already at this point that it is difficult to apply the labor theory of value to productive practices that do not have a given price, that unfold outside of the wage relation" (Arvidsson 2011, 265). "The circumstance that digital labour has no price and that it becomes impossible to distinguish productive time from unproductive time" would make "it difficult to sustain, as Arvidsson (2006), Fuchs (2009a), and Cote and Phybus (2007) have done, that the Marxist concept of 'exploitation' would apply to processes of customer co-production" (Arvidsson $2011,266 f)$. "But since 'free labor' is free, it has no price, and cannot, consequently, be a source of value" (Arvidsson 2011, 266f). Arvidsson's conclusion is that digital labour is not exploited because it has no price (i.e. it is unpaid).

Digital labour is not the only work that has historically been unpaid, one can think also e.g. of housework or slave work. Marxist feminists have argued that houseworkers form an exploited colony of capitalist patriarchy that is locus of "ongoing primitive accumulation" (Mies, Bennholdt- 
Thomsen and Werlhof 1988, 6): they are unpaid, unfree, and fulfil a function for capitalism, and are therefore locus of extreme exploitation. The argument of Marxist feminism is therefore that "subsistence production - mainly performed through the non-wage labour of women and other non-wage labourers as slaves, contracted workers and peasants in the colonies - constitutes the perennial basis upon which 'capitalist productive forces' can be built up and exploited" (Mies 1986, 48).

There is a crucial difference between classical slaves, houseworkers, and corporate Internet users because the first are repressed by physical violence (they are likely to be killed if they stop working), the second are partly coerced by physical violence and feelings of love and affection, whereas the third are ideologically coerced (they are compelled to use the dominant corporate Internet platforms in order to maintain social relations and reputation, if they stop using the platforms, they do not die and are not killed, but are likely to be more isolated). But all three forms of labour produce value that is appropriated by others (the slave master, capitalists and wageworkers, corporations). They are unpaid. Others exploit all of their work time. Arvidsson's assumption that exploitation is only present if a wage is paid downplays the horrors of exploitation and also implies that classical slaves and houseworkers are not exploited. It is furthermore interesting that Arvidsson criticizes himself for sharing the exploitation of free labour approach in a work from 2006.

iPhones, iPads, iMacs, Nokia phones etc are "blood phones", "blood pads", and "blood Macs": Many smartphones, laptops, digital cameras, mp3 players, etc are made out of minerals (e.g. cassiterite, wolframite, coltan, gold, tungsten, tantalum, tin) that are extracted under slave-like conditions from mines in the Democratic Republic of Congo and other countries. The existence of the Internet in its current dominant capitalist form is based on various forms of labour: the relatively highly paid wage work of software engineers (mostly in the West) and low-paid proletarianized workers (mostly in developing countries, but not only) in Internet companies, the unpaid labour of users, the highly exploited bloody Taylorist work and slave work in developing countries producing hardware and extracting "conflict minerals". Arvidsson's approach implies that unpaid Congolese slave workers that extract the material foundations of ICTs are not exploited, which has quite problematic implications.

\section{Capital Accumulation on Social Media}

On corporate social media, users create content, browse content, establish and maintain relations with others by communication, and update their profiles. All time they spend on these platforms is work time. The Internet prosumer commodity that an advertiser buys on e.g. Facebook or Google is based on specific demographic data (age, location, education, gender, workplace, etc) and interests (e.g. certain keywords typed into Google or certain interests identified on Facebook). Thereby a specific group can be identified as target group. All time spent by members of this group on the specific social media platform constitutes the value (work time) of a specific Internet prosumer commodity. This work time contains time for social relationship management and cultural activities that generate reputation. One therefore needs to reflect on how economic value production by the media is connected to what Bourdieu termed social, cultural and symbolic capital (see also Bolin 2011). Users employ social media because they strive to a certain degree for achieving what Bourdieu (1986a, b) terms social capital (the accumulation of social relations), cultural capital (the accumulation of qualification, education, knowledge) and symbolic capital (the accumulation of reputation). The time that users spend on commercial social media platforms for generating social, cultural and symbolic capital is in the process of prosumer commodification transformed into economic capital. Labour time on commercial social media is the conversion of Bourdieuian social, cultural and symbolic capital into Marxian value and economic capital.

Marx formulated the law of value by saying that "the greater the labour-time necessary to produce an article, [...] the greater its value" (Marx 1867, 131). It also applies in the case of commercial social media: The more time a user spends on such platforms, the more data about her/his interests and activities are available and the more advertisements are generated and presented to 
him/her. Users, who spend a lot of time online, create more data and more value (work time) that is potentially transformed into profit.

Arvidsson and Colleoni (2012) argue that social media business models are based on the valorization of affective relations (the number of links to a site on Google, websites, profiles or elements a user likes or assesses positively, expression of positive sentiments towards certain elements, social networks' affectual attachment to an element). As a consequence, "the value of online advertising is not primarily dependent on the number of users that a site can attract websites users like, shared sites or content" (Arvidsson and Colleoni 2012, 144). The "time spent online viewing or interacting with a particular site is not the critical parameter for defining or measuring value in the online advertising environment", rather "affective engagements" and "user affect" (e.g. measured by social buttons, sentiment analysis, network analysis) would be the "source of value" (Arvidsson and Colleoni 2012, 144).

The problems of this approach are that it generalizes the sentiment and affect approach to all corporate online advertising, leaves out the notion of labour, does not study specific platform's capital accumulation models in detail, and that it does not see that affect and sentiments require labour activities that take place in space and time. You do not simply create positive affects, relations, attitudes, and reputations, you work on creating and maintaining them, which is timeintensive and takes place in certain spaces.

Ads on Facebook can be targeted by location (country, city), age, gender, precise interests (keywords can be entered), favourite activities, business and technology interests, family status, consumption interests, mobile phone type, shopping interests, sports interests, connections to a certain Facebook pages or apps, relationship status, relationship interests, languages, education, workplaces (https://www.facebook.com/ads/manage/adscreator, accessed on June 26th, 2012). Facebook's privacy policy (Facebook Data Use Policy, version from June 8th, 2012) explicitly regulates that the following data can be used for targeted advertising: registration information, status updates, friends, likes, places, relationship status, name, pictures, gender, networks, username, user ID, birthday, interactions with other users on Facebook, interactions with pages of apps on Facebook, postings, meta-data sent by the access device (e.g. location data), usage data from games, applications, or websites that co-operate with Facebook, data about users from Facebook's advertising partners, information others share about a user.

This means that Facebook constantly monitors interests, usage behaviour, browsing behaviour, demographic data, user-generated content, social relations, etc. These are individual, affective, social, economic, political, cultural data about users. The more time a user spends on Facebook, the more data is generated about him/her that is offered as a commodity to advertising clients. Exploitation happens in this commodification and production process, whereas the data commodities are offered for sale to advertising clients after the production/exploitation process. The more time a user spends online, the more data is available about him/her that can potentially be sold and the more advertisements can be presented to him/her. Time therefore plays a crucial role on corporate social media. Arvidsson and Colleoni ignore that the labour that generates content, affects, likes, social relations, networks, etc is organised in time and space and that Facebook usage time is productive labour time.

Once value has been created on Facebook by online labour, the resulting data commodities are offered to ad clients with the help of either the pay per click (CPC) or the pay per 1000 impressions (CPM) methods of payment. Here we leave the value-level and commodity production-sphere and enter the price-level and the sphere of commodity sales. How is the social media prosumer commodities' price determined and how is value transformed into money profit? Advertising clients are interested in the access to specific groups that can be targeted with individualized advertising that fit their interests. Access to these groups is sold to advertisers. On Google and Facebook, advertisers set a maximum budget for one ad campaign and a maximum they are willing to pay for one click on their advertisement or for 1000 impressions (=presentations of a targeted ad on a profile). The exact price for one click or for 1000 impressions is determined in a automated bidding process, in which all advertisers interested in a specific group (all ads targeted at this specific group) com- 
pete. In both models, every user is offered as a commodity and commodified, but only certain user groups are sold as commodity. In the pay-per-click model, value is transformed into money (i.e., profit is realized) when a user clicks on an ad. In the pay-per-view model, value is transformed into money (profit is realized) when an ad is presented on a user's profile. The price is mathematically determined by an algorithm and based on bids. The number of hours spent online by a specific group of users determines the value of the social media prosumer commodity. The price of this commodity is algorithmically determined.

All hours spent online by users of Facebook, Google, and comparable corporate social media constitute work time, in which data commodities are generated, and potential time for profit realization. The maximum time of a single user that is productive work time (i.e. results in data commodities) is $100 \%$ of the time spent online. The maximum time that the same user contributes to profit realization by clicking on ads or viewing ads is the time that $\mathrm{s} / \mathrm{he}$ spends on a specific platform. In practice, users only click on a small share of presented ads. So in the pay-per-click accumulation model, work time tends to be much larger than profit realization time. A lot of commodities that are offered for sale are created by online labour, only a certain share of it is sold and results in profits. This share is still large enough so that companies like Google and Facebook can generate significant profits. Online labour time is at the same time potential profit realization time. Capital tries to increase profit realization time in order to accumulate capital, i.e. to make an ever-larger share of productive labour time also profit realization time.

According to Facebook, the price of an ad in a bid is determined by the number of people competing for a specific ad space/target audience, ad quality, ad performance (source: Facebook Help Center, Campaign Cost and Budgeting=>Ads and Sponsored Stories). On Google AdWords, the price of an ad depends on the maximum bids and ad quality. Ad quality is based on an assessment of how relevant and well targeted the text of an ad is (source: Google, video "AdWords: Control Your Costs"): the more targeted an ad, the lower the CPC cost. Google's quality score of an ad is based on the number of past clicks for the targeted keyword, the display URLs number of past clicks, the targetedness of the ad text, the number of past clicks on an ad (source: Google AdWords Help: Quality Score). Google offers like Facebook both CPC and CPM as payment methods. How exactly Google's and Facebook's pricing algorithms work is not known because they are not open source.

According to statistics, the most expensive keywords on Google are insurance, loans, mortgage, attorney, and credit (http://techcrunch.com/2011/07/18/most-expensive-google-adwordskeywords/). The most viewed adds on Facebook are those from the retail sector ( $23 \%$ of all viewed ads), the food \& drinking industry $(19 \%)$, the finance industry $(14 \%)$, the entertainment industry $(11 \%)$, and the games industry (11\%) (http://allfacebook.com/facebook-advertising-rates2 b86020).

A study of Facebook advertising conducted by Comscore (2012) argues that:

- Users spend $40 \%$ of their Facebook time in the news feed, therefore exposure time to adds can be larger there than on brand pages.

- According to DoubleClick, click-through-rates are on average $0.1 \%$.

- Many companies would today mistakenly see the number of fans on brand pages as main success indicator for online advertising.

- People exposed to Facebook ads are more likely to purchase products online or in stores than those who are not exposed. The purchase ratio grows with the length of the advertising campaign. The study therefore suggests the importance of "view-through display ad effectiveness in a medium where click-through rates are known to be lower than average for many campaigns" (Comscore 2012, 3).

Time dimensions play a crucial role in determining the price of an ad: the number of times people click on an ad, the number of times an ad or target URL has already been viewed, the number of times a keyword has been entered, the time that a specific user group spends on the platform. Furthermore, also the bidding maximums used as well as the number of ad clients competing for ad space influence the ad prices. In the pay-per-view method, Facebook and Google earn more 
with an ad that is targeted on a group that spends a lot of time on Facebook. The larger the target group, the higher Facebook's and Google's profits tend to be. In the pay-per-click method, Facebook and Google only earn money if users click on an ad. According to studies, the average clickthrough-rate is $0.1 \%$ (Comscore 2012). This means that Facebook and Google tend to gain more profit if ads are presented to more users.

Generally we can say that the higher the total attention time given to adds, the higher Google's and Facebook's profits tend to be. Attention time is determined by the size of a target group and the average time this group spends on the platforms. Online time on corporate social media is both labour time and attention time: All activities are monitored and result in data commodities, so users produce commodities online during their online time. In the pay per view mode, specific online time of specifically targeted groups is also attention time that realizes profit for Facebook or Google. In the pay per click mode, attention time that realizes profit is only the portion of the online time that users devote to click on ads that are presented to them. In both cases, online time is crucial for a) the production of data commodities, b) the realization of profit derived from the sales of the data commodities. Both surveillance of online time (in the sphere of production) and attention time (in the sphere of circulation) given to advertisements play an important role in corporate social media's capital accumulation model.

According to Google Trends, Michael Jackson was one of the top trending search keywords on Google on June $27^{\text {th }}, 2012$. Using the Google AdWords traffic estimator (on June $27^{\text {th }}, 2012$ ) showed that by creating a campaign with a maximum CPC of $10 €$ and a budget of 1000 Euros per day, one can expect to attract 2867-3504 impressions and 112-137 clicks for total costs of 9001100 Euros per day if one targets Google users who search for "Michael Jackson". In comparison, I used the same settings for the keyword "Cat Power" (an American indie rock singer, much less popular and less sought-after on Google than Michael Jackson). In a campaign that targets users who google "Cat Power", one can expect to attract 108-132 impressions and 3.9-4.7 clicks for total costs of 30.96-37.84 Euros per day. The profit that Google makes with the data commodity associated with the keyword "Michael Jackson" is much larger than the one it makes with the keyword "Cat Power" because the first is a more sought-after keyword. And that a keyword is popular means that users spend more collective usage time per day for entering the keyword and reading result pages than for other keywords. The example shows that popular interests, for whose generation and result consumption users spend more labour time on the Internet than for not-so popular keywords, tend to result in higher profits for Google than interests that are not so popular.

\section{Finance Capital and Social Media}

Google's profits were 9.7 billion US\$ in 2011 (SEC Filings Form 10-K 2011), whereas its financial market valuation (stock market capitalization) was 182 billion US $\$$ on June $26^{\text {th }}, 2012$ (http://money.cnn.com/data/us markets/). Facebook's profits were 1 billion US\$ in 2011 (SEC Filings Form S-1 Registration statement), whereas its stock market capitalization was 70 billion US\$ on June $26^{\text {th }}, 2012$ (http://money.cnn.com/data/us markets/). This shows that the financial market values achieved on the stock market and the profits generated by Internet prosumer commodification do not coincide. Companies like Facebook and Google are overvalued on the stock market, their profits do not match the high market values. This divergence phenomenon is not outside of the logic of Marxist theory, but was rather described by Marx in the analysis of fictitious capital in Capital Volume III.

For Marx, financial capital is based on the formula M (money) - M' (more money). "Here we have M-M', money that produces money, self-valorizing value, without the process that mediates the two extremes" (Marx 1894, 515, see also 471). Consumer credits, mortgages, stock, bonds, and derivates are all based on this financial type of accumulation. Finance capital does not itself produce profit, it is only an entitlement to payments that are made in the future and derive from profits or wages (the latter for example in the case of consumer credits). Marx therefore characterizes finance capital as fictitious capital (Marx 1894, 596). The "share is nothing but an ownership title, pro rata, to the surplus-value which this capital is to realize. A may sell this title to $B$, and $B$ to 
C. These transactions have no essential effect on the matter. A or B has then transformed his title into capital, but $\mathrm{C}$ has transformed his capital into a mere ownership title to the surplus-value expected from this share capital" (Marx 1894, 597f). Financial investments in stocks and financial derivates are transformed into operative capital, but they are not capital themselves, only ownership titles to a part of surplus value that is expected to be produced in the future. "All these securities actually represent nothing but accumulated claims, legal titles, to future production" (Marx 1894, 599). The value of shares is therefore speculative and not connected to the actual profits of the company, but only to expectations about future profits that determine buying and selling decisions of stock investors: "The market value of these securities is partly speculative, since it is determined not just by the actual revenue but rather by the anticipated revenue as reckoned in advance" (Marx 1894, 598, see also 608, 641). The result is a high-risk system of speculation that resembles gambling (Marx 1894, 609) and is crisis-prone (Marx 1894, 621). "Monetary crises, independent of real crises or as an intensification of them, are unavoidable" in capitalism (Marx 1894, 649).

I therefore agree with Arvidsson and Colleoni that financialization is a crucial aspect of corporate social media platforms like Facebook and Google. I do however not agree that this phenomenon cannot be grasped based on a Marxian analysis, but rather argue that financialization is a mechanism that Marx described as important element of capitalism. User labour is the source of profit on these platforms. Finance capital invests in platforms like Facebook and Google because it has the expectation of high future profits. The new economy crisis in 2000 has shown that the difference between stock market values and actual profits can result, as Marx knew, in bursting financial bubbles that result in economic crises. Crises can have multiple sources (e.g. lack of sales = overproduction, underconsumption; class struggle that increases investments and negatively impacts profits (profit-squeeze); overaccumulation; crisis events that trigger large-scale sales of stocks and disappointed investment situations; combinations, etc). The stock market values of companies like Google and Facebook are based on expectations how well these corporations will in the future be able to exploit users' and employees' labour and turn it into profit. The actual profit rates influence, but do not determine stock market investors' buying and selling decisions. The latter are determined by multiple factors and expectations, especially expectations about potential futures, which is the reason why Marx speaks of fictitious capital.

\section{Politics, Alternatives, and Social Transformation}

Arvidsson and Colleoni $(2012,147)$ argue that it is "a toothless argument" to say that the profit generated on the Internet should be redistributed in the form of a basic income because there would not be much available for redistribution. My argument is not that basic income should only be financed by taxing Internet corporations, but that Internet corporations are an example that show that corporations benefit from the exploitation of free labour that creates commons such as culture, knowledge, education, care, social relations, networks, communication, etc. In addition, also nature is a common that is used by capital for free. Given that a lot of non-wage work is productive and exploited, an argument can be made for taxing all profits of all companies to a certain share (e.g. 1$5 \%$ ) and redistributing all resulting revenues in the form of a basic income. The tax can be understood as a small compensation to society for companies' exploitation of society's and nature's commons.

Basic income is an interesting suggestion, politics should however not be reduced to single measures, an impression that Arvidsson and Colleoni create. I not only suggest basic income in the article that Arvidsson and Colleoni criticize, bur rather that we need a "participatory alternative to capitalism" (Fuchs 2010, 193) and that this can only be achieved by an intensification of class struggles combined with politics of radical reformism.

Do Arvidsson and Colleoni suggest alternatives? Do they have a vision of a life beyond capitalism? Open access, data portability, antitrust policies against capital concentration, building alternative platforms are mentioned in their article. They imagine "more 'democratic'" social media (Arvidsson and Colleoni 2012, 147), do not question capitalism as such, but rather suggest a stronger 
regulation of the corporate Internet shall according to this conception exist in parallel with some alternative Internet platforms.

The answer to the question asked in the title of this contribution is that to choose to be without Marx means to be in favour of capitalism and to support ideology, as Adam Arvidsson and Eleanor Colleoni's approach shows very clearly. They advance an approach that is not only directed against Marx, but as a consequence also supportive of capitalism.

Arvidsson (2010) argues for building a peer-review system that is used for the evaluation of products by consumers and producers as an important element of an "ethical economy". Social media, mobile phones and RFID could help to bring about a global and universal quantitative rating system for the economy (Arvidsson 2009). Arvidsson (2008) says that in such a system, the power of consumers and workers would increase, that companies as a result would mainly make money in the financial markets, and that capitalism would "become ethical in new and radical ways" (Arvidsson 2008,336 ). This would mean a "reform of capitalism", the emergence of blended values and of a "global New Deal organised around sustainability and social responsibility" (Arvidsson 2009, 27).

Arvidsson and Colleoni $(2012,147)$ say that their approach is "very un-Marxist in its conclusions". Its political implications show indeed that the motivation for the authors' criticism of Marxist theory is that they want to improve and not abolish capitalism. They imagine a more just, sustainable, and responsible capitalism. This terminology not only fits perfectly into contemporary neoliberal ideology, but is also naïve and idealistic: It ignores that all forms of capitalism are based on inequality and are crisis-prone. And crisis always means misery, precariousness, and more inequality. Capitalism is never responsible, sustainable, or ethical. The suggestion to entrepreneurs that they should support the ethical economy concept because such a transformed economy would enable them to make profits in the financial markets is furthermore arguing for an advancement of financialization and thereby ignores the high crisis-proneness of financial capitalism that has been proofed once more recently in the new world economic crisis. Arvidsson imagines that capitalism and a non-capitalistic economy can friendly co-exist in the form of an ethical capitalism. He thereby ignores the imperialistic and colonialist character of capitalism: imperialism creates milieus of accumulation, i.e. it commodifies spheres of non-capitalist existence in processes that David Harvey (2003) has termed accumulation by dispossession in order to guarantee its further existence. Capitalism is an inherently violent and expansive system that, as history has shown, does not accept any friendly co-existence with non-capitalist systems, but aims at their destruction. The contemporary crisis of capitalism and the existence of global inequality and precariousness have shown that we need alternatives to capitalism in order to create a humane society. My conclusion and approach is therefore in contrast to Arvidsson Marxist in character: it aims at the struggle for a humane, non-capitalist world. In terms of the Internet this means the ethical need of struggles for a non-capitalist Internet and the advancement of non-capitalist Internet platforms that contradict and struggle against the capitalist Internet and aim at the establishment of a communist Internet.

Arvidsson's approach furthermore has also ideological implications. The principles of his concept of the ethical economy have been implemented on a platform called Ethical Economy (http://www.ethicaleconomy.com). Users can select moral values that describe them. There are 33 values available (e.g. environmentalism, fairness, solidarity, tolerance). They can either pre-select definitions of these values by others or give their own definitions. For each value that is added to a profile, actual or desired actions of the user for realizing the specific value can be added. Other users can assess value attainment with the help of a scale that runs from $0 \%$ to $100 \%$. There are various user categories (e.g. activist, entertainer, entrepreneur, politician, student). It is no surprise that on almost all continents that the map that visualizes the distribution of user types geographically, the user category "entrepreneur" is dominating. This shows that the concept of the ethical economy predominantly appeals to capitalists and is therefore likely to function as an ideology that companies employ for creating images of being ethical and responsible. Just like Corporate Social Responsibility, the notion of the ethical economy is "designed to consolidate the power of large corporations" (Banerjee 2008, 59). "Glossy corporate social responsibility reports" and the Ethical Economy rating system alike constitute "a form of 'greenwashing' that often does not reveal the 
grim realities that lie behind them" (Banerjee 2008, 64). It is in this respect no surprise that Arvidsson and Peitersen (2010) assess CSR positively and argue that it means that businesses want to "have a positive social impact" (Arvidsson and Peitersen 2010, 23) and that "business needs to take responsibility for the constructive role that it plays within an emerging ethical economy" (Arvidsson and Peiteresen 2010, 32f).

It is telling that users can only create actions on their own profiles on the Ethical Economyplatform, whereas it is not possible to create actions for other users, which would at least allow some modest criticism of corporate crimes. Furthermore, even if such a system existed, the question is who would conduct such ratings: Corporate criminals (i.e. all capitalist companies) that have enough capital could buy work force that created positive ratings in order to manipulate their public perception. Such a rating system has within capitalism its own political economy. The Ethical Economy rating system is as a consequence a rating system that is primarily intended to and designed to not criticize, but to celebrate capitalist corporations and their exploitative practices.

Arvidsson ignores the material realities and power of actual capital accumulation by substituting a materialistic concept of value and labour by a subjectivistic, idealistic concept of value that exists in an overall capitalistic framework and thereby has ideological implications.

I have at the beginning of this article argued that the digital labour debate features Marxist and non-Marxist as well as critical and administrative positions. It is a debate that is alive, kicking, dynamic, controversial, and ongoing. I have to thank Arvidsson and Colleoni for helping to continue the digital labour debate, although they are not helping to significantly advance it. Arvidsson and Colleoni $(2012,138)$ describe my approach as "orthodox Marxist". The conclusion of my rejoinder is that Arvidsson and Colleoni's approach falls under the category of a non-Marxist and administrative contribution to the digital labour debate that has inhuman political conclusions.

\section{References}

Arvidsson, Adam. 2011. Ethics and value in customer co-production. Massmarketing Theory 11 (3): 261-278.

Arvidsson, Adam. 2010. The ethical economy. New forms of value in the information society? Organization 17 (5): $637-644$.

Arvidsson, Adam. 2009. The ethical economy. Capital \& Class 97: 13-29.

Arvidsson, Adam. 2008. The ethical economy of customer coproduction. Journal of Macromarketing 28 (4): 326-338.

Arvidsson, Adam. 2006. Brands. Meaning and value in media culture. London: Routledge.

Arvidsson, Adam. 2005. Brands. A critical perspective. Journal of Consumer Culture 5 (2): 235-258.

Arvidsson, Adam and Eleanor Colleoni. 2012. Value in informational capitalism and on the Internet. The Information Society 28 (3): $135-150$.

Arvidsson, Adam and Nicolei Peitersen. 2010. The ethical economy (online version). Chapter I: Introduction. http://www.ethicaleconomy.com/files/EthicalEconomy CH1.pdf

Banerjee, Subhabrata Bobby. 2008. Corporate Social Responsibility: The good, the bad and the ugly. Critical Sociology 34 (1): 51-79.

Bolin, Göran. 2011. Value and the media. Cultural production and consumption in digital markets. Farnham: Ashgate.

Bourdieu, Pierre. 1986a. Distinction. A social critique of the judgement of taste. London. Routledge.

Bourdieu, Pierre. 1986b. The (three) forms of capital. In Handbook of theory and research in the sociology of education, ed. John G. Richardson, 241-258. New York: Greenwood Press.

Burston, Jonathan, Nick Dyer-Witheford, and Alison Hearn, ed. 2010. Digital labour. Special issue. Ephemera 10 (3/4): 214539.

Comscore. 2012. The power of Like². How social marketing works. White Paper. http://www.comscore.com/ger/Press Events/Presentations Whitepapers/2012/The Power of Like 2How Social Marketing Works (accessed on June 27th, 2012).

Fuchs, Christian. 2010. Labor in informational capitalism and on the Internet. The Information Society 26 (3): 179-196.

Fuchs, Christian and Rainer Zimmermann. 2009. Practical civil virtues in cyberspace. Towards the utopian identity of civitas and multitudo. Salzburg/München: Shaker.

Hardt, Michael and Antonio Negri. 2004. Multitude. New York: Penguin.

Harvey, David. 2003. The new imperialism. Oxford: Oxford University Press.

Marx, Karl. 1894. Capital: Volume III. London: Penguin.

Marx, Karl. 1867. Capital: Volume I. London: Penguin.

Marx, Karl. 1857/58. Grundrisse. London: Penguin.

CC: Creative Commons License, 2012. 
Mies, Maria. 1986. Patriarchy \& accumultion on a world scale. London: Zed Books.

Mies, Maria, Veronika Bennholdt-Thomsen and Claudia von Werlhof. 1988. Women: the last colony. London: Zed Books.

Scholz, Trebor, ed. 2012. Digital labor. The Internet as playground and factory. New York: Routledge.

Vercellone, Carlo. 2010. The crisis of the law of value and the becoming-rent of profit. In Crisis in the global economy, edited by Andrea Fumagalli and Sandro Mezzadra, 85-118. Los Angeles, CA: Semiotext(e).

Virno, Paolo. 2003. A grammar of the multitude. New York: Semiotext(e).

\section{About the Author}

\section{Christian Fuchs}

Christian Fuchs holds the chair professorship in media and communication studies at Uppsala University's Department of Informatics and Media. He is also board member of the Unified Theory of Information Research Group and editor of tripleC (cognition, communication, co-operation): Journal for a Global Sustainable Information Society. His main research fields are: social theory, critical theory, political economy of media, ICTs, communication, information, technology; critical information society studies, ICTs and society. He is author of numerous academic publications, including the books "Internet and Society: Social Theory in the Information Age" (New York: Routledge 2008, paperback edition 2010) and "Foundations of Critical Media and Information Studies" (New York: Routledge 2011). He is co-founder of the ICTs and Society Network and chair of the European Sociological Association's Research Network 18 - Sociology of Communications and Media Research. 